\title{
Why Darfur? The Responsibility to Protect as a Rallying Cry for Transnational Advocacy Groups
}

\author{
Author's manuscript \\ 17 April 2011 \\ David Lanz, swisspeace \& University of Basel
}

\begin{abstract}
This article explores the role of the Responsibility to Protect (R2P) in the international response to the conflict in Darfur. Both scholars and activists have commonly described the R2P in Darfur as a failure. However, a second look reveals a relatively far-reaching response to a contemporary civil war: Darfur hosts the world's largest UN peacekeeping mission; it represents the first situation that the UN Security Council has referred to the International Criminal Court; sanctions have been imposed against Sudan; and significant resources were invested in peace negotiations. This article thus explores the puzzle of Darfur. It first establishes empirical facts by providing a detailed account of international engagement in Darfur. It then considers four conceptions of the R2P in the context of Darfur, arguing that the R2P as a 'rallying cry' for transnational advocacy groups provides the most plausible explanation for the magnitude of the international response. The third section of the article thus explores the mechanisms through which the transnational campaign on Darfur has built leverage. It concludes by considering the implications of the Darfur case on the R2P as a global norm and by pointing to some of its more problematic aspects.
\end{abstract}

Keywords: Responsibility to Protect, humanitarian intervention, Darfur, Sudan, transnational advocacy networks, framing, grafting, Rwanda analogy

Following NATO's 1999 intervention in Kosovo, the Canadian government set up the International Commission on Intervention and State Sovereignty (ICISS) to clarify under what conditions humanitarian intervention to protect civilians from mass atrocities is permissible. The Commission's report attributed the primary duty of protection to states by virtue of their sovereignty. ${ }^{1}$ Only when a state proves unable or unwilling is the "Responsibility to Protect" transferred to the international community which has a range of measures at its disposal to fulfil its protection duties, including as a last resort, the use of military force. Consequently, the outbreak of violence in the region of Darfur in western

\footnotetext{
${ }^{1}$ ICISS, The Responsibility to Protect (Ottawa: IDRC, 2001).
} 
Sudan became the first test case for the emerging Responsibility to Protect - or R2P in short. As reports of mass atrocities started to filter through in the spring of 2004, a wave of outrage, fostered by extensive media coverage and vocal advocacy campaigns, swept through North America and Western Europe. These campaigns, in accordance with the R2P principle, demanded a forceful international response to the killings in Darfur.

Today, the international response to the Darfur conflict is commonly seen as a failure. Many non-governmental organisations (NGOs) and think tanks have added their voices to this canon. According to Human Rights Watch, in Darfur, 'the world's leaders have failed to deliver on the promises made in the wake of the genocide in Rwanda in 1994 that they would "never again" dither in the face of a possible genocide. ${ }^{2}$ The assessment of the International Crisis Group (ICG) is similar: 'the international community has conspicuously failed to take the steps necessary to protect the people of Darfur. ${ }^{3}$ Likewise, a report by the Council on Foreign Relations argues that the violence in Darfur 'is the most recent case of a state supporting mass atrocity and the rest of the world avoiding efforts to end the killing. ${ }^{4}$ For the Global Centre for the Responsibility to Protect, 'the very word "Darfur" now evokes the failure of the international community to stop war crimes, crimes against humanity, genocide, and ethnic cleansing.' 5

These statements are echoed by scholarly assessments of the performance of R2P in Darfur. Thus, Bellamy and Williams observe an 'apparent contradiction between governments' use of

\footnotetext{
${ }^{2}$ Michael Clough, 'Darfur: Whose Responsibility to Protect?' Human Rights Watch, January 2005, http://www.responsibilitytoprotect.org/files/HRW_Darfur-WhoseResponsibilitytoProtect.pdf (All websites cited in this article were accessed on 31 January 2011.)

${ }^{3}$ Nick Grono, 'Briefing - The International Community's Failure to Protect', African Affairs, 105/421: 621-31 (2006), p. 621. Other ICG reports provide a similar assessment: see 'Darfur: The Failure to Protect', Africa Report No. 89, 8 March 2005; 'To Save Darfur', Africa Report No. 105, 17 March 2006.

${ }^{4}$ Lee Feinstein, 'Darfur and Beyond: What is Needed to Prevent Mass Atrocities', Council on Foreign Relations Special Report No. 22, January 2007, p. 3.

5 James Traub, 'Unwilling and Unable: The Failed Response to the Atrocities in Darfur', Global Centre for the R2P Occasional Paper, 2010, p. 2.
} 
'sovereignty as responsibility' language to enhance their own humanitarian credentials and their unwillingness to take "responsibility-based" action in Darfur. ${ }^{\prime 6}$ For Udombana the international community's passivity in Darfur reveals a 'crisis of humanitarian intervention'? Similarly, Badescu and Bergholm qualify the R2P in Darfur as 'the big let-down'. According to Adelman, the response to the Darfur conflict brings to the fore 'the huge discrepancy between the rhetorical success of the adoption of R2P as an international norm and the absence of practices consistent with that sweeping victory. ${ }^{99}$ Likewise, a recent edited volume concludes that 'the response to the Darfur crisis marks a setback for the idea of an international responsibility to protect civilians at risk of mass atrocities. ${ }^{10}$

Despite the near unanimity of the assessment that Darfur constitutes a failure for the R2P, there are reasons to pause. Short of a non-consensual military intervention, the entire array of conflict management instruments from the ' $\mathrm{R} 2 \mathrm{P}$ toolbox' ${ }^{11}$ has been brought to bear in Darfur. Accordingly, Darfur hosts the world's most expensive and largest UN peacekeeping mission, even as the European Union (EU) deployed its largest ever autonomous military mission across the border in eastern Chad. Furthermore, one of the world's largest humanitarian operations currently operates in Darfur. Likewise, Darfur constitutes the first situation that the UN Security Council referred to the International Criminal Court (ICC), leading to the consequent indictment handed down against the Sudanese President, Omar al-

\footnotetext{
${ }^{6}$ Paul D. Williams and Alex J. Bellamy, 'The Responsibility to Protect and the Crisis in Darfur', Security Dialogue, 36/1, 27-43 (2005), p. 29.

${ }^{7}$ Nsongurua J. Udombana, 'When Neutrality is a Sin: The Darfur Crisis and the Crisis of Humanitarian Intervention in Sudan', Human Rights Quarterly, 27, 1149-1199 (2005).

${ }^{8}$ Cristina G. Badescu and Linnea Bergholm, 'The Responsibility to Protect and the Conflict in Darfur: The Big Let-Down', Security Dialogue, 40/3, 287-309 (2009).

${ }^{9}$ Howard Adelman, 'Refugees, IDPs, and the Responsibility to Protect (R2P): The Case of Darfur', Global Responsibility to Protect, 2/1, 127-148 (2010), p. 127.

${ }^{10}$ David R. Black and Paul D. Williams, 'Conclusion: Darfur's Challenge to International Society' in David R. Black and Paul D. Williams (eds.), The Politics of Mass Atrocities: The Case of Darfur (New York: Routledge, 2010), p. 254.

${ }^{11}$ See Gareth Evans, The Responsibility to Protect: Ending Mass Atrocities Once and for All (Washington, DC: Brookings Institution Press, 2008), pp. 253-54.
} 
Bashir. Significant resources have also been invested in peace negotiations. In addition to the joint mediation efforts of the UN and the African Union (AU), the United States, Russia, China, the UK, France, the EU - to name just the most significant players - have appointed special envoys to Darfur. As such, the international engagement in the Darfur conflict eclipses most other responses to contemporary civil wars in Africa and beyond. This response is puzzling insofar as Darfur does not offer compelling geopolitical advantages for the states involved. Neither are there significant natural resources or transnational terrorist networks operating from Darfur.

Taking these propositions into account, Darfur poses a number of questions: Why has the Darfur conflict triggered a rather far-reaching international response? And what role has the emerging norm of the R2P played in this response? This article aims to contribute to the literature by providing a more differentiated assessment of the R2P in Darfur. It first establishes empirical facts by providing a detailed account of the international response to the Darfur conflict since 2002. The article then considers four conceptions that scholars have put forward to make sense of the R2P in Darfur and beyond: R2P versus Realpolitik; R2P as subversion; R2P as a more just world order; and R2P as social construction. Against this background, the article argues that the most plausible explanation of the response to the Darfur conflict is the emergence of a transnational advocacy movement. The R2P is relevant insofar as it served as a rallying cry for the Darfur activists. Thus, the third section of the article explores the mechanisms through which the transnational campaign on Darfur has built leverage. The conclusion considers the implications of the Darfur case on the R2P as a global norm and points to some of its more problematic aspects. 


\section{Synopsis of the international response to the Darfur conflict}

The international response to the Darfur conflict developed over several stages: in the beginning of the conflict in 2002-04, when the violence reached its peak, there was almost no international reaction. A significant response only emerged in late 2004 after the general public in western countries became aware of Darfur. International engagement in Darfur gradually became more forceful as the focus shifted to robust peacekeeping, sanctions, and international criminal justice.

\section{Absent international reaction at the outset (2002-2004)}

For many years, Darfur was a marginalised region within the Sudanese state given that it was long deprived of resources for economic development and lacked political autonomy. Starting in 2000 , a rebellion began to ferment, eventually leading to the escalation of violence in 2002-03. ${ }^{12}$ The early successes of the rebels threatened the control of the Sudanese government which reacted by arming an existing militia force made up of young men from Arab, mostly nomad tribes in Northern Darfur. These forces were then unleashed, carrying out a vicious counter-insurgency campaign aimed at destroying the civilian support base of the rebels. ${ }^{13}$ The violence reached its zenith between mid-2003 and mid-2004 resulting in the destruction of hundreds of villages of mostly non-Arab tribes, the death of over $130,000^{14}$ and the displacement of 1.5 million Darfurians during that period.

\footnotetext{
${ }^{12}$ For details, see Julie Flint and Alex de Waal, Darfur: A New History of a Long War (London: Zed Books, 2008); Gérard Prunier, Darfur: 21st Century Genocide, Rev. ed. (Ithaca, NY: Cornell University Press, 2008); M. V. Daly, Darfur's Sorrow: A History of Destruction and Genocide (New York, NY: Cambridge University Press, 2007).

${ }^{13}$ Alex de Waal, 'Counter-Insurgency on the Cheap', London Review of Books, 5 August 2004.

${ }^{14}$ Death numbers in the Darfur conflict are contested. The US Government Accountability Office examined various sources of mortality data and concluded that the numbers of the Belgium-based Centre for Research on the Epidemiology of Disasters (CRED) were the most reliable. CRED estimated that 158,000 people had died in Darfur between September 2003 and June 2004, of which 131,000 were excess deaths. (See US Government Accountability Office, 'Darfur Crisis: Death Estimates Demonstrate Severity of Crisis, but Their Accuracy and Credibility Could Be Enhanced', November 2006)
} 
At the same time, the Sudanese government was negotiating a peace deal in Kenya with the Southern insurgents, the Sudan People's Liberation Movement (SPLM). Promising an end to Africa's longest and bloodiest civil war, international actors were entirely focused on these negotiations, as was the attention of the international press. Therefore, at the outset, there was almost no response to the escalating violence in Darfur, aside from the red flags raised by Amnesty International and ICG. ${ }^{15}$ Towards the end of 2003, Eric Reeves, a private activist from the US, denounced the 'ethnic cleansing' in Darfur, ${ }^{16}$ echoing Jan Egeland, the head of UN humanitarian affairs, who had said that Darfur constituted 'one of the worst humanitarian situations in the world' ${ }^{17}$ However, these statements remained without effect until March 2004 when the outgoing UN humanitarian coordinator in Sudan, Mukesh Kapila, said that Darfur was 'the world's greatest humanitarian crisis' and that 'the only difference between Rwanda and Darfur is now the numbers involved' ${ }^{18}$ The inference that genocide was occurring in Darfur was immediately picked up by newspapers in the context of the $10^{\text {th }}$ anniversary of the genocide in Rwanda. Thus, from late March 2004 onwards, editorials about the war in Darfur multiplied, with many authors framing the conflict as genocide. ${ }^{19}$

The growing media attention put Darfur on the radar screen of Christian organisations and of Congresspersons like Frank Wolf and Donald Payne that had a long history of campaigning for South Sudan. As a result of their efforts, in June and July 2004 the US House of

\footnotetext{
${ }^{15}$ See Amnesty International, 'Sudan: Urgent Call for Commission of Inquiry in Darfur as Situation Deteriorates', Press Release, 21 February 2003; ICG, 'Sudan's Other Wars', ICG Africa Briefing, 25 June 2003. ${ }^{16}$ Eric Reeves, 'Human Destruction and Displacement in Darfur: War, Humanitarian Access, and "Ethnic Cleansing"', 12 December 2003, http://www.sudanreeves.org/Sections-article296-p1.html

${ }^{17}$ Quoted in UN News Centre, 'Humanitarian and security situations in western Sudan reach new lows, UN agency says', 5 December 2003, http://www.un.org/apps/news/storyAr.asp?NewsID=9094\&Cr=sudan\&Cr1= ${ }^{18}$ Quoted in IRIN News, 'Sudan: Darfur is World's Greatest Humanitarian Disaster, Says UN Official', 22 March 2004, http://allafrica.com/stories/200403220078.html

${ }^{19}$ Within five weeks of Kapila's statement, the New York Times and the Washington Post alone published ten opinion editorials about Darfur. On the press coverage of Darfur, see Deborah Murphy, 'Narrating Darfur: Darfur in the US Press, March-September 2004' in Alex de Waal (ed.), War in Darfur and the Search for Peace (Cambridge, MA: Harvard University Press, 2007).
} 
Representatives and the Senate unanimously passed a resolution calling the Darfur conflict genocide. The "G-word" gave impetus to an advocacy movement in the US. It brought together human rights, faith-based and student groups under the umbrella of the Save Darfur Coalition, which was established in July 2004. In May, the US State Department opened an investigation to determine whether the atrocities in Darfur did constitute genocide. Based on interviews with Darfurian refugees in Chad, the investigators' answer was affirmative. Therefore, in September 2004, the then Secretary of State Colin Power stated that genocide was occurring in Darfur - the first time the US executive branch used this label to describe an ongoing conflict - although he insisted that this determination did not carry implications for US policy in Sudan. European countries were a bit more reluctant in terms of semantics, although the then UK foreign minister, Chris Mullin, in April 2004 did say that genocide 'may have occurred', ${ }^{20}$ while the European Parliament in September of the same year passed a resolution calling the crimes committed in Darfur 'tantamount to genocide'. ${ }^{21}$

\section{Emergence of an international response (2004-2006)}

Against the backdrop of this growing preoccupation, the world's largest humanitarian operation was set up in Darfur. On account of the substantial contributions of international donors, Darfur has hosted up to 13,000 humanitarian workers and one hundred relief agencies at a time since mid-2004. Their activities have concentrated primarily on camps for internally displaced persons (IDPs), whose numbers rose from 1.5 million in 2004 to 2.7 million in $2008 .^{22}$

\footnotetext{
${ }^{20}$ Quoted in Chris Marks, 'Sudan links genocide claim to US poll', The Scotsman, 11 September 2004.

${ }^{21}$ European Parliament, 'Motion for a Resolution on the Humanitarian Situation in Sudan', 16 September 2004, http://www.europa-eu-un.org/articles/en/article_3810_en.htm

${ }^{22}$ Fabrice Weissman, 'Humanitarian Dilemmas in Darfur' MSF Foundation, July 2008, http://www.msfcrash.org/crash/drive/b4d8-fw-2008.humanitarian-dilemmas-in-darfur.pdf
} 
The first international organisation to respond to the Darfur conflict was the AU, owing to its recent commitment to offer "African solutions for African problems". ${ }^{23}$ Under its auspices, in April 2004, the Darfur rebels and the Sudanese government signed the N'Djamena Humanitarian Ceasefire Agreement. The agreement was never implemented, but it established the African Union Mission (AMIS) as a monitoring force. Initially, AMIS only had a few hundred peacekeepers; subsequently however, thanks to significant EU funding, their numbers increased up to 6,000 soldiers. Thus, AMIS went beyond monitoring and took on protection tasks, in particular around IDP camps. ${ }^{24}$ Despite its achievements, ${ }^{25}$ AMIS was eventually judged to be inept, as activists in the US and Europe called for a more robust UN replacement mission that could better protect vulnerable populations in Darfur. ${ }^{26}$

Calls for a UN peacekeeping mission made Darfur a prominent issue in the corridors of the UN headquarters in New York. However, even beforehand, Darfur was high on the agenda of the then Secretary-General Kofi Annan. In September 2004, the UN Security Council set up an International Commission of Inquiry to investigate the crimes committed in Darfur and more specifically to determine whether genocide had occurred. Its verdict was that there was insufficient proof for genocide in Darfur, but that the crimes that were committed were 'no less heinous than genocide'. ${ }^{27}$ The Commission also recommended that the Security Council refer the situation in Darfur to the ICC. The US was at first opposed to the referral, proposing instead the establishment of an ad hoc tribunal for Darfur. After intense lobbying by human

\footnotetext{
${ }^{23}$ Cristina Badescu and Linnea Bergholm, 'The African Union' in Black and Williams (eds.), The Politics of Mass Atrocities.

${ }^{24}$ See Paul D. Williams, 'Military Responses to Mass Killings: The African Union Mission to Sudan', International Peacekeeping, 13/2, 168-183 (2006).

${ }^{25}$ See William G. O'Neill and Violette Cassis, 'Protecting Two Million Internally Displaced: The Successes and Shortcomings of the African Union in Darfur', Brookings-Bern Project on International Displacement, November 2005.

${ }^{26}$ For a critical account of this process, see Mahmood Mamdani, 'Blue-hatting Darfur', London Review of Books, 6 September 2007.

27 'Report of the International Commission of Inquiry on Darfur to the UN Secretary-General', 25 January 2005, http://www.un.org/news/dh/sudan/com_inq_darfur.pdf, p. 4.
} 
rights NGOs and some Darfur advocates and in order not to upset its European allies, the US finally decided to abstain, thereby allowing the Council to refer a situation to the ICC for the first time. ${ }^{28}$ The ICC Prosecutor quickly opened investigations, but it took roughly two years until the Court issued its first arrest warrants: one against a minister in the Sudanese government, Ahmed Haroun, the other against a senior militia leader by the name of Ali 'Kushayb'. Although these people are not among the most senior leadership within the Sudanese government, Khartoum refused to surrender them to the ICC. ${ }^{29}$

Meanwhile, international efforts were under way to mediate a political settlement between the Sudanese government and the Darfur rebel movements, principally the Sudan Liberation Army/Movement (SLA/M) and the Justice and Equality Movement (JEM). After the failure of the N'Djamena Ceasefire Agreement, a new process was launched in Abuja at the end of 2004. The AU was again the main mediator, along with international observers from the US and European governments that funded the peace negotiations. The negotiations continued until early 2006 when the patience of the sponsors eventually ran out. Thus, an end date for the Abuja talks was set, while coercive 'deadline diplomacy' was used to persuade the parties to sign an agreement. ${ }^{30}$ The pressure divided the rebel movements. JEM and the SLM/A faction of Chairman Abdel Wahid opted out, whereas the SLM/A faction led by Minni Minawi, together with the Sudanese government, signed the Darfur Peace Agreement (DPA). ${ }^{31}$

\footnotetext{
${ }^{28}$ On the European factor, see Rebecca Hamilton, Fighting for Darfur: Public Action and the Struggle to Stop Genocide (Basingstoke, Palgrave Macmillan, 2011), pp. 55-69. For examples of the advocacy push for the ICC, see Samantha Power, 'Court of First Resort', New York Times, 10 February 2005; Amnesty International, 'Sudan: ICC Must Be Allowed to Prosecute War Crimes and Crimes against Humanity', 1 February 2005; Human Rights Watch, 'U.S. Proposal for a Darfur Tribunal: Not an Effective Option to Ensure Justice', 15 February.

${ }^{29}$ See William A. Schabas, 'The International Criminal Court' in Black and Williams (eds.), The Politics of Mass Atrocities.

${ }^{30}$ See Laurie Nathan, 'No Ownership, No Peace: the Darfur Peace Agreement', LSE Working Paper, September 2006.

${ }^{31}$ See Alex de Waal, 'I Will not Sign', London Review of Books, 30 November 2006.
} 
Towards a more forceful response (2006-2009)

One of the reasons why the US, the UK and others were eager to bring the Abuja talks to a close was their desire to deploy a UN peacekeeping mission in Darfur, which required clear guidelines from a peace agreement. Most activists abandoned calls for a non-consensual military intervention, but they upheld the claim that external intervention was required to protect civilians in Darfur. A strong UN peacekeeping force with a robust mandate under Chapter VII of the UN Charter was seen as the appropriate means to this end. ${ }^{32}$ The Abuja talks therefore needed to produce a settlement as quickly as possible - according to some observers, this mind-set led to the use of coercive methods at the expense of a sound negotiation process. ${ }^{33}$

However, the Sudanese government was strongly opposed to a UN peacekeeping mission in Darfur. Khartoum only gave its tentative acquiescence after obtaining a series of concessions and, most importantly, when Beijing shifted its position towards the mission in the wake of the NGO-led "Genocide Olympics" campaign. ${ }^{34}$ Thus, in the July 2007 Resolution 1769, the UN Security Council established the joint AU-UN Mission in Darfur (UNAMID). ${ }^{35}$ The founding resolution stipulated that the new mission should be of 'predominantly African character' - a concession to the Sudanese government - and it authorised the deployment of nearly 26,000 military and police personnel. With a budget of approximately USD 1.5 billion, UNAMID was to become the UN's largest and most expensive peacekeeping force. The

\footnotetext{
${ }^{32}$ For an argument in this regard, see ICG, 'To Save Darfur'.

${ }^{33}$ This point is made in particular by Alex de Waal, who participated in the Abuja negotiations as an advisor to the mediation team: Alex de Waal, 'Darfur and the Failure of the Responsibility to Protect', International Affairs, 83/6, 1039-1054, (2007).

${ }^{34}$ See Courtney J. Richardson, 'Social Influence and Peacekeeping Participation? China and the UN-AU Mission in Darfur, 2004 - 2007', Paper presented at the Annual Convention of the International Studies Association, Montreal, 16-19 March 2011.

${ }^{35}$ It appears that at China's behest, a specific reference to R2P was removed from the draft text of Resolution 1769, although the Security Council did give UNAMID a mandate to 'protect civilians' under Chapter VII of the UN Charter.
} 
mission became operational in 2008, although it faced delays in the deployment of troops and equipment.

The US, a strong supporter of the UNAMID mission, has emerged as the country with the toughest stance against its former Cold War-ally. Owing in large part to the work of student activists, Congress unanimously adopted the 2007 Sudan Accountability and Divestment Act, which requires companies applying for US government contracts to prove that they were not conducting business in Sudan. ${ }^{36}$ The executive level was pro-active as well: in 2007, President Bush announced sanctions against high-ranking officials of the Sudanese government and companies operating in Sudan. Khartoum managed to offset some of this pressure by collaborating with the US on anti-terrorist matters. The extent of this collaboration is opaque, although it appears that the then head of intelligence, Salah Gosh, was invited to Washington DC by the CIA in April 2005. ${ }^{37}$ There were also currents within the administration that did not want to upset the implementation of the north-south peace agreement, signed by the Sudanese government and the SPLM in January $2005 .^{38}$ Nevertheless, the Darfur issue has prevented normalisation, resulting in a continued strain in the relationship between the US and Sudan. ${ }^{39}$

European countries were somewhat less forceful than the US, although the European Commission has also imposed sanctions on the Sudanese government. These include an arms embargo as well as financial and travel restrictions for individuals who are deemed to

\footnotetext{
${ }^{36}$ See Luke A. Patey, 'Against the Asian Tide: The Sudan Divestment Campaign', Journal of Modern African Studies, 47/4, 551-73 (2009).

${ }^{37}$ See Ken Silverstein, 'Official Pariah Sudan Valuable to America's War on Terrorism', Los Angeles Times, 29 April 2005.

${ }^{38}$ For example, at a public event in April 2006, the then US Deputy Secretary of State, Robert Zoellick, spoke about the need to balance US steps on Darfur with the objective of promoting the implementation of the northsouth peace agreement. (See The Brookings Institution, 'Current Policy Options for Darfur', 13 April 2006, transcript available from http://www.brookings.edu/ /media/Files/events/2006/0413africa/20060413.pdf) ${ }^{39}$ For example, Sudan is one of only four countries on the US State Department's list of state sponsors of terrorism, http://www.state.gov/s/ct/c14151.htm
} 
undermine stability in Darfur. ${ }^{40}$ Europe's response intensified when Bernard Kouchner was appointed foreign minister of France in April 2007. Kouchner was active in the French campaign on Darfur and he took up the issue on his very first day in government. After an initial misconceived idea to enforce humanitarian corridors in Darfur, he proposed the establishment of a peacekeeping force in eastern Chad and north-eastern Central African Republic (CAR) with the aim of containing the Darfur conflict across the border. ${ }^{41}$ After much negotiation within the EU, the establishment of the EU Force (EUFOR) Chad/CAR was eventually approved. It was deployed in March 2008 for one year, before being handed over to a UN follow-on mission, whose mandate ran out at the end of 2010. EUFOR Chad/CAR was the EU's largest and most expensive military mission outside of Europe ever: it included 3,700 troops, $60 \%$ of which came from France, and cost at least $€ 800$ million. ${ }^{42}$

After the peak in 2004, violence in Darfur gradually diminished. As a result of the influx of aid, mortality rates in Darfur were brought back to pre-war levels, although pockets of excess mortality continue to exist. ${ }^{43}$ Intra-rebel fighting intensified in the aftermath of the DPA, as non-signatory rebels and their signatory counterparts, who were now allied with the Sudanese government, attacked one another. ${ }^{44}$ At the same time, banditry and attacks against humanitarian organisations increased, as did inter-tribal clashes. The AU and the UN's efforts to bring the parties back to the negotiation table failed in 2007. The following year, the peace

\footnotetext{
${ }^{40}$ A detailed list of EU sanctions against Sudan is available from: http://ec.europa.eu/external_relations/cfsp/sanctions/docs/measures_en.pdf

${ }^{41}$ See Antoine Glaser and Stephen Smith, Sarko en Afrique (Paris: Plon, 2008), pp. 62-64.

${ }^{42}$ See Frédéric Mérand and Haingo Mireille Rakotonirina, 'La force européenne au Tchad et en Centrafrique: le baptême du feu', Politique Africaine 114, 105-125 (2009).

${ }^{43}$ Weissman, "Humanitarian Dilemmas".

${ }^{44}$ Abdul-Jabbar Fadul and Victor Tanner, 'Darfur after Abuja: A View from the Ground' in Alex de Waal (ed.), War in Darfur.
} 
process was taken over by a joint AU-UN mediator, Djibril Bassolé, although his efforts have not borne fruit. ${ }^{45}$

The peace process was further complicated by the ICC Prosecutor's announcement in July 2008 to charge Sudan's President, Omar al-Bashir with war crimes, crimes against humanity, and genocide. In March 2009, the ICC Pre-Trial Chamber confirmed the indictment and issued an arrest warrant against al-Bashir. Khartoum reacted angrily by temporarily suspending cooperation with international agencies and by expelling 13 international humanitarian NGOs from Darfur. Most western countries including the US welcomed the ICC's decision, even as it obscured their relations with Khartoum. In the African context, the indictment caused a backlash: at the AU summit in June 2009, a resolution was passed in which African governments announced their refusal to cooperate with the ICC in the Bashir case.

Despite the presence of a robust peacekeeping force, the situation on the ground in the aftermath of the southern Sudan referendum of January 2011 is volatile. The level of battlerelated violence in Darfur is relatively low, although it has flared up in 2010 and in early 2011, as the government stepped up its attacks against the rebels. However, the conflict remains unresolved; inter- and intra-tribal violence has become more frequent; the majority of Darfurians still depends on humanitarian aid, while many of them are stuck in IDP camps, without the prospect of returning home.

\footnotetext{
${ }^{45}$ See Julie Flint, 'From Rhetoric to Reality: The Failure to Resolve the Darfur Conflict', Small Arms Survey, January 2010.
} 


\section{Darfur in the context of the Responsibility to Protect}

The previous section described the international response to the Darfur conflict, which, as Mills noted, was contradictory at times. ${ }^{46}$ The following section seeks to understand why this response occurred. For this purpose, it considers four theoretical propositions regarding the role of R2P and assesses their plausibility in the context of Darfur: R2P versus Realpolitik; R2P as subversion; R2P as a more just world order; and R2P as a social construction.

$R 2 P$ versus Realpolitik

According to a realist perspective, states intervene in far-away civil wars when material interests are at stake, for example to eliminate safe havens for terrorists or to prevent 'rogue' states from acquiring nuclear weapons. ${ }^{47}$ Thus, states do not get involved out of humanitarian compassion or a sense of collective responsibility and therefore, the lofty principles of R2P falter against Realpolitik. ${ }^{48}$ Worse, Kuperman argues that the emerging R2P norm creates a moral hazard, encouraging insurgents to escalate violence in order to attract international intervention. ${ }^{49}$ Indeed, realism has emerged as the dominant argument in the assessment of the R2P in Darfur, among activists, pundits and scholars alike. According to this perspective, in contrast to the promise of $\mathrm{R} 2 \mathrm{P}$, there was no meaningful intervention to protect vulnerable populations in Darfur, either because states did not care or had contrary interests in the form of oil or counterterrorism. Christopher Hitchens' verdict is representative of many voices: 'it looks as if the realists won the day in the matter of Darfur., 50

\footnotetext{
${ }^{46}$ Kurt Mills, 'Vacillating on Darfur: Responsibility to Protect, to Prosecute, or to Feed?' Global Responsibility to Protect, 1/4, 532-59 (2009).

47 James D. Fearon and David D. Laitin, 'Neo-trusteeships and the Problems of Weak States', International Security, 28/4, 5-43 (2004), p. 6.

${ }^{48}$ For a summary of realist objections to humanitarian intervention, see Jennifer Welsh, 'Taking Consequences Seriously: Objections to Humanitarian Intervention' in Jennifer Welsh (ed.), Humanitarian Intervention and International Relations (Oxford: Oxford UP, 2004).

${ }^{49}$ Alan J. Kuperman, 'The Moral Hazard of Humanitarian Intervention: Lessons from the Balkans', International Studies Quarterly 52, 49-80 (2008).

${ }^{50}$ Christopher Hitchens, 'Realism in Darfur', Slate Magazine, 7 November 2005, http://www.slate.com/id/2129657/
} 
The Realpolitik framework is useful for explaining why there was no full-fledged military intervention to stop the atrocities in Darfur in 2003 - a measure that some observers believe the R2P norm required states to do ${ }^{51}$ Arguably, the only country that would have been capable of carrying out such an intervention is the US, either unilaterally, as they did in Iraq, or by leading a multilateral mission like in Kosovo. Indeed, it appears that there were serious discussions about this option within the Bush Administration. ${ }^{52}$ In the end, the opponents of air strikes against Sudan prevailed for two reasons. First, a military intervention in Darfur would have been very costly, in particular since the US military was already overstretched by the engagements in Afghanistan and Iraq. Second, the gains from a military intervention in Darfur would have been minimal as Darfur does not host any terrorist networks nor does it have lucrative natural resources. Moreover, another US-led invasion of a Muslim country would have likely had negative repercussions, providing terrorist groups with propaganda material to incite further violence against the US.

Therefore, realism offers a plausible explanation for what the US and other governments did not do in Darfur. However, it is much less compelling and even paradoxical in explaining their actual involvement. The US' primary interest in Sudan in terms of Realpolitik is to ensure that the country does not become an operating ground for terrorists, as was the case during the 1990s when Osama bin-Laden was based in Sudan. A second consideration could be to gain access to oil contracts, the most lucrative of which are held by China, currently Sudan's principal ally. A third interest is to secure the implementation of the north-south peace agreement, which is crucial for stability in the broader Horn of African region. The cooperation of the Sudanese government is instrumental for achieving all of these objectives

\footnotetext{
${ }^{51}$ E.g. Williams, "Military Responses".

${ }^{52}$ Personal interview with Jendayi Frazer, US Assistant Secretary of State for African Affairs 2005-2009, Washington DC, 9 March 2010.
} 
and therefore, the most rational strategy would be for the US to foster a positive relationship with Khartoum. Therefore, if Realpolitik considerations prevailed, the US would handle Sudan in a similar fashion to its strategic relationships with, for example, Saudi Arabia. This was indeed the case in the late 1970s when Sudan aligned itself with the US and was rewarded with large sums of economic aid and military assistance. ${ }^{53}$

There are elements of cooperation in the current US policy towards Sudan, which have led advocacy groups to criticise the US response as being too weak on Darfur. However, despite the geopolitical rationale as well as support for normalisation among the intelligence community, a number of influential Christian evangelist leaders, ${ }^{54}$ and potentially, the US oil industry, the general attitude of the US towards Sudan has remained adverse. This is exemplified by the multi-layered sanctions regime against Khartoum, the US government's public support for the ICC indictment against the President of Sudan, and the continued listing of Sudan as one of only four states sponsoring terrorism. The Sudan policy of other western governments, such as the UK and France, are characterised by similar paradoxes.

\section{$R 2 P$ as subversion}

Another critical appraisal of the R2P is offered by pluralist scholars. Thus, international institutions such as the framework regulating the use of force in the UN Charter as well as the principles of sovereignty and non-interference guarantee order in the international system. The idea of humanitarian intervention subverts these principles and it therefore jeopardises

\footnotetext{
${ }^{53}$ See J. Millard Burr and Robert O. Collins, Requiem for Sudan: War, Drought and Disaster Relief on the Nile (Boulder, CO: Westview Press, 1995).

${ }^{54}$ For example, Franklin Graham, evangelist leader and spiritual mentor of George W. Bush, argued for the deferral of the ICC indictment of Omar al-Bashir on the grounds of it obstructing the north-south peace process. (See Franklin Graham, 'Put Peace Before Justice', New York Times, 3 March 2009)
} 
the legitimacy of the international system. ${ }^{55}$ According to Jackson, the destabilising effect of such subversion may even result in war. ${ }^{56}$ More starkly, scholars of postcolonialism see in the R2P a potential neo-colonial conspiracy insofar as it seeks to erode the very institutions that protect the powerless from the powerful. This perception is underpinned by what Chomsky in a 2009 debate on R2P called 'the rattling of a skeleton in the closet': the many cases in history when humanitarian pretexts were used to justify imperial interventions. ${ }^{57}$ According to Chandler,

Opponents of intervention, mainly non-Western states, have been sceptical of the grounds for privileging a moral justification for interventionist practices and have expressed concern that this shift could undermine their rights of sovereignty and possibly usher in a more coercive, Western-dominated, international order. ${ }^{58}$

A version of this argument in the context of Sudan was articulated in a 2009 book by Mahmoud Mamdani. He sees the advocacy campaign spearheaded by the Save Darfur Coalition as 'the humanitarian face of the war on terror' aimed at stigmatising the Sudanese government. ${ }^{59}$ The campaign itself as well as the various interventions that it fostered, for example the ICC's indictment of President al-Bashir, served to weaken Sudan as a country and make it more vulnerable to external influence. In Mamdani's view, the R2P in Darfur was thus turned into 'a slogan that masks the big power agenda to recolonize Africa' ${ }^{60}$

Mamdani usefully reminds us that external interventions in civil wars are often conflated with the self-interested motives of intervening states. However, the premise that the R2P is merely

\footnotetext{
55 See Mohammed Ayoob, 'Humanitarian Intervention and State Sovereignty', International Journal of Human Rights, 6/1, 81-102 (2002).

${ }^{56}$ Robert Jackson, The Global Covenant, Human Conduct in a World of States (Oxford, Oxford UP, 2000).

${ }^{57}$ Noam Chomsky, 'Statement to the UN General Assembly Thematic Dialogue on the Responsibility to Protect', 23 July 2009, http://www.un.org/ga/president/63/interactive/protect/noam.pdf, p. 1.

${ }^{58}$ David Chandler, 'The Responsibility to Protect? Imposing the "Liberal Peace", International Peacekeeping, 11/1, 59-81 (2004), p. 60.

${ }^{59}$ Mahmood Mamdani, Saviors and Survivors: Darfur, Politics and the War on Terror (New York, NY: Pantheon Books, 2009), p. 6.

${ }^{60} \mathrm{Ibid}$, p. 300. An assessment of this argument in the context of the UN Security Council is contained in: Alex J. Bellamy, 'Responsibility to Protect or Trojan Horse? The Crisis in Darfur and Humanitarian Intervention after Iraq', Ethics \& International Affairs, 19/2, 31-54 (2005).
} 
a vehicle of big power interests, and the analysis of the international response to the Darfur conflict as a neo-colonial campaign against Sudan's independence, does not seem plausible. As mentioned above, if western states were primarily interested in Sudan's oil, or if they wanted to bring Sudan into their sphere of influence, a policy of patronage and accommodation would have been more sensible. However, due to their engagement in Darfur, the US and EU countries have actually lost influence in Sudan, as the country has moved closer to China and states of the Arab League. Moreover, some organisations that responded to the R2P in Darfur - most importantly the African Union - come from the global south and can hardly be accused of spearheading a neo-colonial conspiracy.

\section{$R 2 P$ as a more just world order}

Another proposition regarding the $\mathrm{R} 2 \mathrm{P}$ is derived from liberal internationalism and the solidarist branch of the so-called "English School". The central tenet of liberal internationalists is that democracies do not fight wars against each other, although they do behave aggressively towards authoritarian states. ${ }^{61}$ Therefore, in order to build a more peaceful world, liberals have promoted democracy, human rights, and the rule of law, in particular in states emerging from armed conflict. ${ }^{62}$ This is not far from the position of solidarists: order and justice are complementary and therefore states should strive towards greater justice within international society. ${ }^{63}$ Scholars from both traditions make a normative case for the R2P. Liberals appreciate the R2P for its contribution to a world based on good governance and human rights, ${ }^{64}$ while solidarists see in the concept the realisation of the idea

\footnotetext{
${ }^{61}$ See Michael Doyle, 'Kant, Liberal Legacies and Foreign Affairs', Philosophy and Public Affairs 12/3, 205235 (1983).

${ }^{62}$ See Roland Paris, At War's End (New York: Cambridge UP, 2004).

${ }^{63}$ See Hedley Bull, 'The Grotian Conception of International Society' in Herbert Butterfield and Martin Wight (eds.), Diplomatic Investigations: Essays in the Theory of International Relations (London: Allen \& Unwin, 1966).

${ }^{64}$ See e.g. Thomas G. Weiss, Humanitarian Intervention (London: Pluto, 2007).
} 
of justice in international society. ${ }^{65}$ For both, the emergence of the R2P potentially constitutes an element of a more just world order.

As mentioned in the introduction, most observers with a liberal inclination see Darfur as a failure of the R2P and describe international engagement in Darfur as too little, too late. More recently however, more nuanced assessments have come to the fore. Bellamy argued that the criticism of R2P in Darfur needs to be 'tempered somewhat' considering that 'since 2004, the Security Council has been actively seized by the matter and has responded with a raft of measures. ${ }^{96}$ Most notably, ICISS co-chair Gareth Evans argued that the inability here to use coercive military measures does not mean that [Darfur] is a case of "R2P failure": it just means that the international responsibility to protect the people of Darfur ... has to take other forms, including the application of sustained diplomatic, economic, and legal pressure. $^{67}$

These accounts point to an alternative reading of the international response to the Darfur conflict from a liberal and solidarist perspective. Thus, the world community did more in Darfur than in most previous civil wars to address the plight of affected populations: peacekeepers with a robust mandate were deployed to offer some protection to civilians; the ICC was given a mandate to prosecute those responsible for crimes in Darfur; sanctions were imposed against the Sudanese government; much effort was put into negotiating a peace settlement; and a massive humanitarian operation was set up to secure the livelihoods of those who lost their homes in the war. In other words, the magnitude of the international reaction to the Darfur crisis could be interpreted as an imperfect, but significant step towards a new world order as outlined by the R2P doctrine.

\footnotetext{
${ }^{65}$ See Nicholas Wheeler, Saving Strangers: Humanitarian Intervention in International Society (Cambridge: Cambridge UP, 2000).

${ }^{66}$ Alex J. Bellamy, 'The Responsibility to Protect - Five Years On', Ethics \& International Affairs, 24/3, 143169 (2010), p. 153.

${ }^{67}$ Gareth Evans, 'The Responsibility to Protect: An Idea Whose Time Has Come... and Gone?' International Relations, 22/3, 283-298 (2008), pp. 293-93.
} 
However, two facts about the international engagement in Darfur contradict the notion that states have internalised the R2P norm. First, as described above, the world community only became interested in Darfur after the worst atrocities took place, namely in the second half of 2004. During the most brutal phase of the conflict from mid-2003 to mid-2004, there was practically no international reaction. Second, states did not autonomously respond to the Darfur conflict. For the most part, they reacted to civil society pressure. Without it, it is unlikely that the US' genocide determination, US sanctions against Khartoum, China's shift of position with regards to UNAMID, and France's sponsorship of EUFOR would have materialised.

$R 2 P$ as social construction

According to the constructivist approach, systems of shared ideas and norms constitute important vectors for states' behaviour in world politics by shaping their social identities. However, international norms do not emerge from a vacuum, but they are 'actively built by agents having strong notions about appropriate or desirable behaviour in their community. ${ }^{96}$ According to Finnemore, the norm of humanitarian intervention, as articulated in the R2P doctrine, has gained salience in recent years. ${ }^{69}$ This is the result of two changes in the normative structure of world politics. First, the notion of who is human and can therefore claim protection has become universal. And second, the 'internationally shared view about what governments owe their citizens' has evolved so that 'governments are expected to guarantee and provide a bundle of rights and services'. ${ }^{70}$ These changes have been made

\footnotetext{
${ }^{68}$ Martha Finnemore and Kathryn Sikkink, 'International Norm Dynamics and Political Change', International Organization, 52/4, 887-917 (1998), p. 896.

${ }^{69}$ See Martha Finnemore, The Purpose of Intervention: Changing Beliefs About the Use of Force (Ithaca, NY: Cornell UP, 2003); Martha Finnemore, 'Paradoxes in Humanitarian Intervention' in Richard Price (ed.), Moral Limit and Possibility in World Politics (Cambridge: Cambridge UP, 2008).

${ }^{70}$ Finnemore, 'Paradoxes', p. 203.
} 
possible by 'an increasingly dense network of human rights norms, law and transnational activist groups that all persuade (or coerce) policy makers and publics to support these [humanitarian] interventions. ${ }^{71}$ In this sense, the R2P norm provides a 'rallying cry' around which norm entrepreneurs can mobilise. ${ }^{72}$ Their actions are indeed crucial because, as Wheeler argued, 'it is only through the mobilisation of intense pressures on the part of domestic publics that governments will be prepared to embark on humanitarian policies. ${ }^{, 73}$

Darfur is a case in point. The growing salience of the R2P norm is a necessary condition for states to contemplate intervention in a strategically unimportant region like Darfur. However, such intervention is not automatic, as the muted response to the recent atrocities in Sri Lanka demonstrates. Rather, it was the work of advocacy groups that put Darfur on the map. Specific platforms were created in several countries to coordinate the advocacy efforts of a broad range of NGOs. These efforts achieved a lot of resonance due to a favourable political context, but also because the Darfur campaign was malleable to the interests of different constituencies. ${ }^{74}$ The glue that held the different groups together was a commitment to the R2P norm. Indeed, the language of R2P was very present in the Darfur campaigns, which were fuelled by the activists' outrage over the world's inability to prevent genocide ten years after Rwanda. Accordingly, they demanded international intervention to protect innocent civilians from harm. Moreover, many well-known advocates of the R2P - such as Samantha Power, Elie Wiesel, and Romeo Dallaire - acted as their mentors. Not surprisingly, according

\footnotetext{
71 Ibid.

${ }^{72}$ Evans, ‘An Idea Whose Time', p. 294. This interpretation is consistent with Stamnes' view of R2P as a 'speech act' that serves to catalyze international action in situations of mass atrocities: Eli Stamnes, "'Speaking the R2P" and the Prevention of Mass Atrocities", Global Responsibility to Protect, 1/1, 70-89 (2009), p. 70.

${ }^{73}$ Nicholas Wheeler, 'Agency, Humanitarianism and Intervention', International Political Science Review, 18/1, 9-25 (1997), p. 22.

74 See David Lanz, 'Commentary - Save Darfur: A Movement and its Discontents', African Affairs, 108/433, 669-677 (2009).
} 
to two activists, the R2P principle constituted the 'intellectual underpinning' of the Darfur advocacy movement. ${ }^{75}$

The movement gained considerable leverage and its lobbying was an important factor in generating international action in Darfur, as exemplified by the involvement of the ICC, EUFOR, and UNAMID. This claim is corroborated by the fact that the international response only materialised after the movement became operational. Furthermore, the states in which the Darfur advocates were most influential, namely the US, the UK and France, have shown the most significant response, even as they resisted calls to intervene militarily. Robert Zoellick, the then Deputy Secretary of State, said about Darfur: 'I have dealt with a lot of foreign policy issues ... and I am not sure I have one that has generated as much interest across a wide spectrum of Americans as this one has. ${ }^{76}$ According to Williams, "one of the main driver[s] of UK policy on Darfur came in the form of activism from a wide range of civic associations. ${ }^{77}$ In the context of France's 2007 presidential election, activists associated with the Urgence Darfour platform elicited commitments on Darfur from all candidates. According to Roland Marchal, 'Once Sarkozy got elected, he wanted to show some fidelity to the commitments he made throughout his electoral campaign. Darfur was one of these..., ${ }^{78}$

\section{The Responsibility to Protect and the Darfur narrative}

The previous section considered varying perspectives regarding the role of the R2P in the international response to the Darfur conflict. It concluded that the R2P was most relevant as a

\footnotetext{
${ }^{75}$ Colin Thomas-Jensen and Julia Spiegel, ‘Activism and Darfur: Slowly Driving Policy Change', Fordham International Law Journal, 31/4, 843-858 (2008), p. 205.

76 The Brookings Institution, 'Current Policy Options for Darfur'.

${ }^{77}$ Paul D. Williams, 'The United Kingdom' in Black and Williams (eds.), The Politics of Mass Atrocities, p. 202.

${ }^{78}$ Roland Marchal, 'Understanding French Policy Toward Chad/Sudan? A Difficult Task (2)', Blog post, 5 June 2009, available from <http://blogs.ssrc.org/sudan/2009/06/05/understanding-french-policy-toward-chadsudan-adifficult-task-2/>
} 
rallying cry around which the interests of a diverse set of advocacy groups could converge and which served as a mobilising device. However, several questions remain unanswered: Why was the R2P as a rallying cry more effective in Darfur than elsewhere? And how has the Darfur advocacy movement achieved exceptional resonance in public opinion and among policy makers? To tackle these questions, the following section considers three mechanisms derived from the literature on transnational advocacy movements through which activists created political will for engagement in Darfur: creating frames, grafting and invoking analogies.

\section{Creating frames}

The most important factor of salience, both in public opinion and among decision makers is the narrative that advocates have created to frame the Darfur conflict. The story that emerges from early accounts in Western media paints Darfur as a place of good and evil, of victims and perpetrators, and of villains and heroes: vicious 'Arab' militia, allied with the government in Khartoum, commit genocide against the 'African' populations of Darfur. In order to save the victims and bring the perpetrators to justice, the West needs to do what it failed to do in Rwanda in 1994: to muster a humanitarian intervention. This summary is a caricature, but it does capture the main features of Darfur as an issue when it first appeared in the media in $2004 .^{79}$ As the conflict in Darfur progressed and the common knowledge of Darfur increased, some nuances were added. Nonetheless, the main features of the Darfur narrative - genocide, Arab vs. African, and the need for external intervention - have remained constant over the years.

\footnotetext{
${ }^{79}$ Murphy, 'Narrating Darfur'.
} 
The creation of cognitive frames to raise awareness about an issue is a common strategy employed by transnational advocacy networks. ${ }^{80}$ Frames make issues comprehensible to external audiences and they encourage collective action. ${ }^{81}$ Thus, according to Snow and Benford, the more a frame is coherent internally and the more it fits the broader political culture, the greater is the 'frame resonance'. ${ }^{82}$ The Darfur advocacy movement was effective precisely because it achieved exceptional frame resonance. Two factors pertaining to the Darfur narrative are relevant in this regard. First, the narrative describes the Darfur conflict in morally unambiguous terms. In the accounts of activists, there is absolute clarity about good and evil and about the identities of victims and perpetrators. They made few attempts to shed light on the complex causes of the Darfur conflict and instead explained violence as the projection of evil. Not surprisingly therefore, the activist narrative drew criticisms from longtime Darfur experts. Julie Flint, for example, complained that for the activists 'Darfur is not a place with a complex history; it is a moral high ground. ${ }^{83}$ In spite of this, the Darfur narrative proved to be compelling for the broader public. It offered an easy explanation of the war and aroused a lot of sympathy for the victims.

The second factor contributing to the resonance of the Darfur narrative is closely related to the R2P doctrine. The narrative suggests that external intervention is the remedy to 'save Darfur'. In the early days of activism, a number of advocates spoke about the need for a nonconsensual military intervention, ${ }^{84}$ although many subsequently moderated their stance and demanded a robust peacekeeping mission instead. Evidently, the emphasis on external

\footnotetext{
${ }^{80}$ Margaret E. Keck and Kathryn Sikkink, Activists Beyond Borders: Advocacy Networks in International Politics (Ithaca, NY: Cornell UP, 1998), p. 17.

${ }^{81}$ Ibid.

${ }^{82}$ David A. Snow and Robert D. Benford, 'Ideology, Frame Resonance, and Participant Mobilization' in Bert Klandermas, Hanspeter Kriesi, and Sidney Tarrow (eds.), From Structure to Action: Comparing Social Movement Research across Cultures (Greenwich, CT: JAI Press).

${ }^{83}$ Julie Flint, 'Darfur, Saving Itself', Washington Post. 3 June 2007.

${ }^{84}$ See e.g. Eric Reeves 'Regime Change in Sudan', Washington Post. 23 August 2004.
} 
intervention reflects the $\mathrm{R} 2 \mathrm{P}$ doctrine which prescribes this course of action when mass atrocities are ongoing and the home government is unable or, as in the case of Sudan, unwilling to stop them. The Darfur narrative thus put Western countries in the role of the saviours, as their power can potentially be used for a good moral purpose. This frame struck a chord among decision makers, in particular in the US, whose moral leadership was questioned in the context of the 2003 Iraq invasion. A tough stance on Darfur provided an opportunity to reclaim the moral high ground and as a result, both Democrats and Republicans, embraced Darfur as a cause. Likewise, Sarkozy and Kouchner saw intervention in the Darfur conflict as an opportunity to reaffirm France's moral leadership in the world.

\section{Grafting}

A second mechanism through which Darfur activists have built leverage is related to what Price has termed 'grafting': the association of a new norm with a pre-existing broadly accepted norm. ${ }^{85}$ As argued above, the campaign for Darfur represents an attempt to put the R2P norm into practice. Associations were established with two related normative constellations. First, Darfur advocates linked their campaign to the anti-genocide norm. Enshrined in the 1948 Genocide Convention, which defines genocide as acts committed with the intent to destroy a national, ethnic, racial or religious group, this norm stipulates that states have a duty to prevent the commission of genocide as well as to punish its perpetrators. Thus, anti-genocide and R2P norms are natural allies since they both prescribe action to stop atrocities that constitute genocide. In the case of Darfur, a link between the two norms was created by framing the conflict as genocide. Indeed, since Powell's declaration, Darfur advocates have insisted on the 'G-word', brushing away discussions about whether Darfur

\footnotetext{
${ }^{85}$ Richard M. Price, 'Reversing the Gun Sight: Transnational Civil Society Targets Land Mines', International Organization, 52/3, 613-644 (1998), p. 617.
} 
really constitutes genocide and whether the genocide actually ended when the violence diminished after $2004 .{ }^{86}$

The effect of the grafting was that many supporters of the anti-genocide norm have become keen advocates of international intervention in Darfur. Samantha Power, whose 2002 book $A$ Problem from $\mathrm{Hell}^{87}$ was instrumental in popularising the anti-genocide norm, was active from the outset in the Darfur advocacy movement. She served as an advisor and mentor to student activists, and her own field research-based report about the atrocities in Darfur had a significant impact on the nascent Darfur activist movement. ${ }^{88}$ Several student leaders refer to Power's book as the 'bible' of student activism for Darfur. ${ }^{89}$

Another icon of the movement to prevent genocide was Holocaust survivor and Nobel Peace Laureate Elie Wiesel who spoke frequently about the war in Darfur and participated in the founding meeting of the Save Darfur Coalition. His engagement created buy-in among many Jewish organisations that got involved in the grassroots mobilisation around Darfur. The Holocaust Memorial Museum in Washington DC played a particularly important role in raising awareness about Darfur. The Museum had its own outreach activities, and it provided support for student activists that spearheaded Darfur campaigns on college campuses all over the US..$^{90}$

\footnotetext{
${ }^{86}$ An interesting episode occurred in 2008 when Andrew Natsios, the then US government's Special Envoy to Sudan, suggested in a Senate Foreign Relations Committee testimony that the situation in Darfur does not constitute genocide anymore. This suggestion elicited strong reactions by a number of senators who had previously championed Darfur as an issue. (See Mamdani, Saviors and Survivors, pp. 34-38)

${ }^{87}$ Samantha Power, A Problem from Hell: America and the Age of Genocide (New York, NY: Basic Books, 2002).

${ }^{88}$ Power travelled to Darfur in summer 2004 and subsequently wrote about her experience: Samantha Power, 'Dying in Darfur: Can the Ethnic Cleansing in Sudan Be Stopped', The New Yorker, 30 August 2004.

${ }^{89}$ Personal interviews, Washington DC, February-March 2010.

90 See Rebecca Hamilton and Chad Hazlett, "Not on Our Watch": The Emergence of the American Movement for Darfur' in Alex de Waal (ed.), War in Darfur.
} 
Second, the campaign built leverage by grafting the Darfur issue on existing global justice norms. This refers to the idea that people who committed acts qualifying as war crimes, crimes against humanity, or genocide must be held accountable regardless of when and where these crimes took place. There is of course an intrinsic link between global justice norms and the $\mathrm{R} 2 \mathrm{P}$ doctrine, which includes judicial measures as part of its prevention and reconstruction agenda. From the outset, Darfur advocates demanded that perpetrators of genocide in Sudan be brought to justice. Such claims were picked up by established human rights organisations. Some of them, for example Amnesty International and Human Rights First, joined the Save Darfur Coalition, adding legitimacy and resources to the Darfur campaign as a result.

\section{Invoking analogies}

The third mechanism of resonance is related to what Keck and Sikkink called 'accountability politics': efforts by transnational advocacy networks to build support for their cause by 'hold[ing] power actors to their previously stated policies and principles. ${ }^{\text {'91 }}$ In the case of Darfur, this consisted of invoking analogies between the Darfur conflict and the Rwandan genocide in 1994, thereby reminding policy makers of the promises they had made in its aftermath. This fell on particularly fertile grounds in the US, where many policy makers have expressed remorse over their failure to act on Rwanda. ${ }^{92}$ During a 1998 visit to Kigali, then US President Bill Clinton summarised the lessons of Rwanda as follows: 'The international community ... must bear its share of responsibility for this tragedy. We did not act quickly enough after the killing began ... We did not immediately call these crimes by their rightful name: genocide. ${ }^{93}$ This lesson was of course central to the emergence of the R2P, premised

\footnotetext{
${ }^{91}$ Keck and Sikkink, Activists Beyond Borders, p. 16.

${ }^{92}$ See Roberta Cohen, 'Darfur Debated', Forced Migration Review, 29, $55-57$ (2007).

${ }^{93}$ Quoted in Michael Barnett, Eyewitness to Genocide: the United Nations and Rwanda (London: Cornell UP, 2002), p 155.
} 
on the conviction that if atrocities as horrific as those in Rwanda were to happen again, forceful action must be taken to stop them.

From the very beginning of the Darfur advocacy movement - in fact, since Kapila's statement in March 2004 - Darfur was framed as 'another Rwanda.' It therefore became a test case for the many commitments of 'never again' that states readily asserted after Rwanda. ${ }^{94}$ The effect of the Darfur-Rwanda analogy was twofold: one was that it stimulated media attention. Liberal pundits, such as Nicholas Kristof from the New York Times started to write prolifically about the Darfur conflict after Kapila's whistle-blowing.

The second effect of the Darfur-Rwanda analogy was felt at the decision-making level. Some of the most active promoters of international engagement in Darfur were senior officials whose personal experiences in the context of the Rwandan genocide left a strong mark. For example, Kofi Annan's role as the head of UN peacekeeping during the Rwandan genocide has been critically scrutinised, and Annan has since been an ardent supporter of humanitarian intervention. ${ }^{95}$ From early on, Annan spoke forcefully about Darfur and personally made sure it was given top priority within the UN Secretariat. ${ }^{96}$ Susan Rice, the current US Ambassador to the UN, who was on Bill Clinton's National Security Council staff in 1994, was particularly pro-active on Darfur. In an opinion-editorial of May 2004, admitting that she remains 'haunted by the Rwanda genocide', Rice called for military intervention in Darfur. ${ }^{97}$ Later, she continued to advocate for tough action against the Sudanese government. ${ }^{98}$ Bernard

\footnotetext{
94 Daren Brunk, 'Dissecting Darfur: Anatomy of a Genocide Debate', International Relations, 22/1, 25-44 (2008), p. 38.

${ }^{95}$ See James Traub, The Best Intentions: Kofi Annan and the UN in the Era of American World Power (New York: Macmillan, 2006).

${ }^{96}$ Confidential interview with a senior UN Official, New York, March 2010.

${ }^{97}$ Susan E. Rice and Gayle E. Smith, 'The Darfur Catastrophe', Washington Post, 30 May 2004.

98 See Susan E. Rice, 'The Genocide in Darfur: America Must Do more to Fulfill the Responsibility to Protect', Brookings Institution, 2007, http://www.brookings.edu/papers/2007/1024darfur_rice_Opp08.aspx.
} 
Kouchner, who was instrumental for France's involvement in Darfur, also has a personal connection to Rwanda. During the genocide, Kouchner travelled to Kigali to airlift orphans back to France and he strongly supported his country's military mission in June 1994. For Kouchner, the world's failure to stop the Rwandan genocide represents 'the childhood sins of the right of ingérence.${ }^{99}$ Mukesh Kapila, the first person to call Darfur genocide, was marked by his experience as one of the first British government officials to visit Rwanda after the genocide in $1994 .{ }^{100}$ Finally, Roméo Dallaire, the famous force commander of the ill-fated UN peacekeeping mission during the Rwandan genocide, became an active campaigner for Darfur. In fact, Dallaire's editorial ‘Looking at Darfur, Seeing Rwanda’ played an important role in popularising the Darfur-Rwanda analogy. ${ }^{101}$ These personalities exemplify the power of invoking analogies: they perceived resolute action over Darfur as a form of redemption for the international community's dubious inaction, and even their personal failings, during the Rwandan genocide.

\section{Conclusion}

Why has the conflict in Darfur triggered a far-reaching international response, and what role did the emerging norm of the R2P play in shaping this response? This article has argued that the magnitude of international engagement in Darfur was made possible by the evolution of normative structures, shifting the borders of legitimacy away from non-interference towards responsibility. The response actually materialised when civil society networks tapped into this structure and used the R2P norm as a rallying cry to persuade states to do something to alleviate the suffering of people in Darfur. The campaign for Darfur achieved exceptional resonance, both with public opinion and among policy makers. This resonance stemmed from

\footnotetext{
${ }^{99}$ Quoted in James Traub, 'A Statesman without Border', New York Times Magazine. 3 February 2008.

${ }^{100}$ Kapila provides a personal testimony in the film "Moving from Words to Action: The Responsibility to Protect", http://www.aegistrust.org/Films/moving-from-words-to-action-the-responsibility-to-protect.html ${ }^{101}$ Romeo Dallaire, 'Looking at Darfur, Seeing Rwanda', New York Times. 4 October 2004.
} 
the political strategies of Darfur advocates, including the framing of the Darfur conflict in clear moral and political categories; the grafting of Darfur to existing anti-genocide norms; and the invocation of analogies between the war in Darfur and the 1994 genocide in Rwanda.

What does Darfur tell us about the current state of the R2P? First, compared to other civil wars, the international response to the Darfur conflict constitutes a relatively ambitious implementation of the $\mathrm{R} 2 \mathrm{P}$ doctrine. One conclusion, therefore, is that the $\mathrm{R} 2 \mathrm{P}$ is no longer purely aspirational, but has gained practical relevance. Second, Darfur shows that the function of the $\mathrm{R} 2 \mathrm{P}$ as a rallying cry for transnational activism has potential. Thus, the R2P's normative content appears to be at least as significant as the very broad policy platform that it sets out. Considering these two factors, why is the R2P in Darfur so commonly described as a failure? One explanation is the $\mathrm{R} 2 \mathrm{P}$ has not yet emancipated itself from the idea of military humanitarian intervention, despite affirmations to the contrary by advocates and policy makers. Many of them remain stuck in a logic that considers anything less than NATO's intervention in Kosovo as failure, even though the R2P doctrine actually emphasises nonmilitary instruments of conflict prevention.

Another reason is that Darfur is not, evidently, a success for the R2P. The international community only started paying attention to the Darfur conflict when the majority of the atrocities had already happened. Moreover, the interventions that did take place failed to significantly improve the situation of Darfurians on the ground. Humanitarian access has improved and the presence of international actors presumably has a certain deterrence effect, but there is no doubt that civilians in Darfur remain intensely vulnerable. It is easy to blame these failures on the lack of "political will" to intervene more forcefully. Less convenient is the realisation that the $\mathrm{R} 2 \mathrm{P}$ doctrine itself, and the different interventions it inspired, had 
problematic consequences in Darfur. Thus, according to de Waal, the insistence of Darfur activists on military intervention has crowded out political strategies to solve the crisis through peace negotiations. ${ }^{102}$ Similarly, Belloni has argued that the R2P provided an incentive for the Darfur rebels to escalate their struggle, hoping that such action would lead to the desired external intervention. ${ }^{103}$ Likewise, a number of observers have pointed to the ambiguous impact of the ICC indictments against the Sudanese President. ${ }^{104}$ Finally, some civil society representatives from Darfur are highly critical of UNAMID given the mission's collaboration with the Sudanese government. An assessment of the merits of these arguments is beyond the scope of this paper. They do, however, remind us that when it comes to the impact of the R2P, in Darfur and beyond, it is best to shed the simplistic language of success and failure.

\footnotetext{
102 De Waal, 'Darfur and the Failure of the Responsibility to Protect'.

${ }^{103}$ Roberto Belloni, 'The Tragedy of Darfur and the Limits of the "Responsibility to Protect"', Ethnopolitics, 5/4, 327-346 (2006).

${ }^{104}$ See e.g. Rob Crilly, Saving Darfur: Everyone's Favorite African War (London: Reportage Press, 2010).
} 